\title{
PARTISIPASI MASYARAKAT DALAM PELAKSANAAN MUSYAWARA PEMBANGUNAN ( MUSREMBANG ) DESA DI DESA LEPPANGENG KECEMATAN PITU RIASE KABUPATEN SIDENRENG RAPPANG
}

\author{
IRMAWATI \\ Universitas Muhammadiyah Sidenreng Rappang \\ E-mail:irma.sidrap@gmail.com
}

\begin{abstract}
Abstrak
Musrenbang adalah forum antarpelaku dalam rangka menyusun rencana pembangunan Nasional dan rencana pembangunan Daerah. Musrenbang diatur dalam Undang-Undang no. 25 tahun 2004 tentang Sistem Perencanaan Pembangunan Nasional dan diatur oleh Menteri Perencanaan Pembangunan Nasional/Bappenas untuk tingkat nasional dan Badan Perencanaan Pembangunan Daerah (Bappeda). Kegiatan ini berfungsi sebagai proses negosiasi, rekonsiliasi, dan harmonisasi perbedaan antara pemerintah dan pemangku kepentingan non pemerintah.
\end{abstract}

Pelaksanaan Musrenbang Desa adalah kegiatan perencanaan pembangunan yang dilakukan di desa bertujuan untuk meningkatkan kualitas dan kuantitas pembangunan yang ada di desa. Pelaksanaan Musrenbang Desa diatur dalam SPPN UU NO 25 Tahun 2004 dan Permendagri No 66 Tahun 2007 Mengenai Perencanaan Desa yang juga menjadi landasan Pelaksanaan Musrenbang Desa. Penelitian ini membahas tentang peran aktor dalam pelaksanaan Musrenbang Desa bertujuan untuk mengetahui dan menganalisis sejauh mana peran yang dilakukan oleh aktor sebagai steakholder dan sebagai perwakilan masyarakat, untuk menyampaikan usulan perencanaan pembangunan desa dan mempertahankan usulan guna menjadi prioritas usulan rencana pembangunan desa pada pelaksanaan Musrenbang Desa, yang kemudian akan diajukan pada pelaksanaan Musrenbang Kecamatan. 
Partisipasi dalam pemanfaatan hasil, partisipasi masyarakat ini tidak sesuai dengan yang ada dilapangan sebab masyarakat tidak menyukai pelaksanaan musyawarah rencana pembangunan yang diadakan di desa karena setiap pelaksanaan musyawarah rencana pembangunan tidak melibatkan masyarakat.Menemukan bahwa masyarakat yang sebenarnya sangat menyukai dengan adanya musrembang yang diadakan di desa Leppangeng tetapi hasil dari musrembang itu tidak sesuai dengan yang diusulkan oleh masyarakat setempat untuk kepentingan bersama.Hasil musrembang hanya mementingkan kepentingan-kepentingan sepihak saja.

\section{kata kunci : Partisipasi, Masyarakat, Musrembang}

\section{PENDAHULUAN}

Partisipasi masyarakat sangatlah berpengaruh terhadap pengambilan keputusan, dimana partisipasi masyarakatsebagai salah satu elemen proses pembangunan desa, karena itu partisipasi masyarakatdalam pelaksanaan pembangunan desa perlu dibangkitkan terlebih dahulu. Partisipasi masyarakatyang merupakan tolak ukur dalam menilai apakah merupakan proyek pembangunan masyarakat atau bukan.

Pembangunan desa sebagaimana dituangkan dalam Undang-Undang Nomor 6 tahun 2014 tentang Desa adalah, pasal 78: pembangunan desa bertujuan meningkatkan kesejahteraan masyarakat desa dan kualitas hidup menusia serta penanggulangan kemiskinan melalui pemenuhan kebutuhan dasar, pembangunan sarana dan prasana desa, pengembangan potensi ekonomi lokal, serta pemanfaatan sumber daya alam dan lingkungan secara berkelanjutan. Tujuan pembangunan pedesaan jangka panjang adalah peningkatan kesejahteraan masyarakat pedesaan secara langsung melalui peningkatan kesempatan kerja, kesempatan berusaha dan pendapatan berdasarkan pendekatan bina lingkungan, bina usaha dan bina manusia, dan secara tidak langsung adalah meletakkan dasar- dasar yang kokoh bagi pembangunan nasional.

Di dalam hal musyawarah di Desa, masyarakat tidak pernah diundang untuk hadir dalam musyawarah. Tanpa adanya partisipasi dari masyarakat atau tanpa 
pelibatan dalam hal pengambilan keputusan justru menjadi pertanyaan besar bagi masyarakat, kenapa, dan apa alasanya. Transparansi sangatlah dibutuhkan masyarakat guna mencapai tujuan dan kepentingan bersama, untuk mensejahterakanmasyarakat Di Desa. Musyawarah perencanaan pembangunan yang di singkat musrenbang adalah forum antar pelaku dalam rangka menyusun rencana pembangunan nasional dan rencana pembangunan daerah.

\section{TINJAU PUSTAKA}

\section{TEORI PARTISIPASI}

Totok dalam (Mustanir, Dema, Syarifuddin, Meity, \&Wulandari, 2018; Mustanir \& Lubis, 2107; Mustanir, Ahmad; Barisan, Hamid, 2017; Latif et al., 2019) mengatakan bahwa partisipasi adalah turut sertanya masyarakat pada proses mengidentifikasi potensi dan masalah, ikut sertanya masyarakat dalam pengambilan keputusan, pelaksanaan keputusan, serta keterlibatan dalam proses evaluasi kegiatan. Partisipasi masyarakat menekankan pada "partisipasi" warga secara langsung di lembaga dan dalam proses pemerintahan. Adisasmita dalam solekhan (2014: 141) mengemukakan bahwa partisipasi masyarakat marupakan keterlibatan dalam pelibatan anggota masyarakat dalam pembangunan, mulai dari perencanaan sampai dengan pelaksanaan pada masyarakat lokal.

\section{JENIS DAN BENTUK PARTISIPASI}

Adisasmita dalam (Sapri et al., 2019) mengemukakan jenis partisipasi terdiri dari:

a. Partisipasi uang/harta benda yaitu partisipasi dalam memberikan harta benda atau uang.

b. Partisipasi tenaga yaitu memberikan sumbangsih tenaga fisik dalam pelaksanaan kegiatan. Partisipasi keterampilan adalah memberikan keahlian yang dimiliki kepada masyarakat lainnya yang membutuhkan.

c. Partisipasi ide pikiran adalah partisipasi berupa sumbangan pikiran, pendapat yang konstruktif dalam memperlancar pelaksanaan program dan mengembangkannya. 
d. Partisipasi didalam pengambilan kebijakan, dimana masyarakat terlibat dalam setiap kegiatan pengambilan kebijakan yang ada kaitannya dengan kepentingan bersama.

\section{PARTISIPASI MASYARAKAT}

1. Pengertian Partisipasi Masyarakat

Menurut (A. Mustanir, Yasin, et al. 2018) terdapat beberapa pengertian dasar mengenai partisipasi masyarakat, di antaranya adalah sebagai berikut

a. Partisipasi masyarakat adalah peran serta masyarakat dalam berbagai kegiatan individu, kelompok atau badan hukum yang timbul atas kehendak dan keinginan sendiri ditengah masyarakat, untuk berminat dan bergerak di penyelenggaraan penataan ruang (Barisan, Ramadhan, and Mustanir 2017) (A. Mustanir and Rusdi 2019).

b. Partisispasi masyarakat adalah keterlibatan masyarakat sesuai dengan hak dan kewajibannya sebagai obyek dan subjek pembangunan, keterlibatan dalam tahap pembangunan dimulai sejak tahap perencanaan sampai pengawasan berikut segala hak dan tanggun jawabnya (A. Mustanir 2016) (A. Mustanir, Justira, et al. 2018).

Partisipasi masyarakat merupakan suatu peran di mana terdapat adanya pembangunan untuk menuju kepada peningkatan taraf hidup masyarakat tersebut. Karenanya,partisipsi masyarakat dalam lingkungan pedesaan merupakan manifestasi terhadap peran masyarakat dalam mendukung suatu perubahan sosial melalui hubungan timbal balik antara masyarakat dan desa. Artinya bahwa adanya ketergantungan antara masyarakat dengan desa dalam upaya peningkatan atau kemajuan baik masyarakatnya maupun desanya secara universal.

2. Jenis Dan Bentuk Partisipasi Masyarakat

Adisasmita dalam (Sapri et al.,2019) mengemukakan jenis partisipasi yaitu :

a. Partisipasi uang/harta benda yaitu partisipasi dalam memberikan harta benda atau uang. 
b. Partisipasi tenaga yaitu memberikan sumbangsih tenaga fisik dalam pelaksanaan kegiatan. Partisipasi keterampilan adalah memberikan keahlian yang dimiliki kepada masyarakat lainnya yang membutuhkan.

c. Partisipasi ide pikiran adalah partisipasi berupa sumbangan pikiran, pendapat yang konstruktif dalam memperlancar pelaksanaan program dan mengembangkannya.

d. Partisipasi didalam pengambilan kebijakan, dimana masyarakat terlibat dalam setiap kegiatan pengambilan kebijakan yang ada kaitannya dengan kepentingan bersama.

Sedangkan Solekhan (2014:153) mengatakan bahwa bentuk partisipasi masyarakat pada intinya ada (empat) macam, yaitu :

a. Partisipasi dalam pembuatan keputusan

b. Partisiasi dalam pelaksanaan

c. Partisipasi dalam menerima manfaat

d. Partisipasi dalam evaluasi

3. Indikator Partisipasi Masyarakat

Indikator dalam penelitian ini menurut (Totok Mardikanto 2013: 67; Letiecq \& Schmalzbauer, 2012; Matarrita-Cascante \& Brennan, 2012; Rolfe, 2016; Sudhipongpracha, 2013; Usadolo \& Caldwel, 2016; Woodyard, Przybyla, \& Hallam, 2015) menyatakan bahwa partisipasi terdiri dari empat :

a. Partisipasi untuk mengidentifikasi masalah. Ini biasanya berkaitan dengan penentuan alternatif dari berbagai gagasan yang menyangkut kepentingan bersama. Partisipasi jenis ini sangat penting, karena masyarakat menuntut untuk terlibat dalam menentukan masalah, arah dan orientasi pembangunan.

b. Partisipasi untuk ikut dalam pengambilan keputusan. Ini berkaitan dengan penetuan alternatif gagasan dan partisipasi semacam ini penting bagi masyarakat dalam menentukan arah dan orientasi pembangunan mereka.

c. Partisipasi untuk ikut dalam pelaksanaan program pembangunan yang telah dirumuskan dalam rencana yang telah menjadi kesepakatan. 


\section{PENGERTIAN MUSREMBANG}

Musrenbang adalah sebuah mekanisme perencanaan, sebuah institusi perencana yang ada di daerah dan sebagai mekanisme untuk mempertemukan usulan/kebutuhan masyarakat (bottom up planning) dengan apa yang akan diprogram pemerintah (tp down planning).

Musrenbang digunakan sebagai wadah penyusunan rencana pembangunan nasional, baik di pusat maupun di daerah (UU NO 25 tahun 2004, pasal1:6) pelaksanaan pembangunan nasional, baik di pusat dan daerah di dasarkan demokrasi dengan prinsip-prinsip kebersamaan berkeadilan, berkelanjutan berwawasan lingkungan, serta kemandirian dengan menjaga keseimbangan kemajuankesatuan nasional (UU NO.25 tahun 2004, pasal 2:7) Musrembang yang selalu diadakan di desa Leppangeng bagi masyarakat setempat hanya membuangbuang waktu serta anggaran jika hasilnya tidak sesuai dengan keinginan dan kepentingan masyarakat desa.

Masyarakat desa Leppangeng juga menganggap dan berharap kedepannya dengan diadakan musrembang janganlah mengutamakan kepentingan pemangku kepentingan dalam desa maupun pribadi melainkan untuk kepentingan bersamasama untuk kemajuan dan perkembangan desa Leppangeng.Dengan adanya musrembang yang dilaksanakan di desa diharapkan menjadi suatu tolak ukur menjadikan desa itu bertumbuh ataupun sebaliknya. Respon positif dari masyarakat dan pemerintah desa menentukan perkembangan desa itu tetapi jika respon pemerintah dan masyarakat bertentangan maka hasil dari musrembang itu sendiri pasti hasilnya negatif sehingga partisipasi masyarakat juga menurun drastis.

Musrembang dilaksanakan dalam setiap desa ialah bertujuan mensejahterakan masyarakat lewat program-program unggulan yang dibuat dan disepakati bersama. Oleh karena itu,setiap musrembang wajib masyarakat dilibatkan sehingga terjadi saling percaya dan keterbukaan antara pemerintah desa dan masyarakat setempat. Partisipasi masyarakat akan meningkat jika pemerintah desa memberikan ruang dan kepercayaan serta transparansi kepada masyarakat di desa 
Leppangeng yang adalah masyarakat setempat dimana kerja sama akan terjalin sebagai patner membangung desa bersama-sama untuk generasi yang akan datang.

Dalam pelaksanaan Musrenbang Desa terdapat faktor yang menjadi pendukung dan penghambat pelaksanaan Musrenbang desa.Faktor pendukung merupakan bagian dari terlaksananya suatu kegiatan, apa yang menyebabkan kegiatan tersebut dapat berlangsung. Hasil peneliatian yang dilakukan peneliti menemukan adanya faktor pendorong pelaksanaan Musrenbang Desa, diantaranya adalah:

1. Adanya semangat dan keinginan dari sebagain masyarakat untuk berpartisipasi dalam pelaksanaan Musrenbang

2. Proses sosialisasi yang optimal.

Faktor penghambat partisipasi masyarakat dalam pelaksanaan Musrenbang Desa adalah hal yang membuat pelaksanaan tidak berjalan secara sempurna. Hal- hal yang menjadi permasalahan dalam pelaksanaan Musrenbang Desa, diantanya adalah :

1. Hambatan partisipasi masyarakat secara internal dalam pelaksanaan Musrenbang Desa.

2. Sistematika Pelaksanaan Musrenbang

\section{KONSEP PERENCANAAN PEMBANGUNAN}

Perencanaan pada dasarnya merupakan cara, teknik atau metode untuk mencapai tujuan yang diinginkan secara tepat; terarah dan efisien sesuai dengan sumberdaya yang tersedia. Dengan demikian, secara umum perencanaan pembangunan adalah cara atau teknik untuk mencapai tujuan pembangunan secara tepat, terarah dan efisien sesuai dengan kondisi negara atau daerah bersangkutan. Sedangkan ujuan pembangunan pada umumnya adalah untuk mendorong proses pembangunan secara lebih cepat guna mewujudkan masyarakat yang maju, makmur dan sejahtera.

Perencanaan pembangunan merupakan suatu tahapan awal dalam proses pembangunan. Sebagai tahapan awal, perencanaan pembangunan akan menjadi 
bahan/pedoman/acuan dasar bagi pelaksanaan kegiatan pembangunan (Riyadi \& Bratakusumah, 2004) (Mustanir and Rusdi. Muhammad 2019).

Perencanaan pembangunan juga berlaku bagi negara-negara yang sedang berkembang, karena ada bebrapa faktor, yaitu karena kegagalan mekanisme pasar, ketidakpastian masa datang, untuk mengarahkan kegiatan pembangunan. Indonesia merupakan salah satu negara berkembang yang tak luput dengan mekanisme parencanaan pembangunan dengan adanya SPPN (system perencanaan pembangunan nasional) Undang-Undang Nomor 24 Tahun 2004. Yang mana perencanaan pembangunan bukan hanya dilakukan pada tingkat pusat namun pada tingkat daerah juga.

2. Tujuan dan Fungsi Perencanaan Pembangunan

Berdasarkan dengan Undangundang No. 25 Tahun 2004, dalam rangka mendorong proses pembangunan secara terpadu efisien, perencanaan pembangunan di Indonesia mempunyai 5 tujuan dan fungsi pokok.

a. Mendukung koordinasi antar pelaku pembangunan.

b. Menjamin terciptanya integrasi, singkronisasi dan sinergi antar daerah, waktu dan fungsi pemerintah, baik pusat maupun daerah.

c. Menjamin keterkaitan dan konsistensi antara perencanaan, penganggaran pelaksanaan dan pengawasan.

d. Mengoptimalkan partisipasi masyarakat dalam perencanaan pembangunan.

e. Menjamin tercapainya penggunaan sumberdaya secara efisien, efektif dan adil.

\section{LINGKUP PARTISIPASI MASYARAKAT DALAM PEMBANGUNAN}

Lingkup partisipasi dengan bertolak pada urutan proses perencanaan pembangunan, maka secara rinci jenis partisipasi dalam pembangunan sebagai berikut :

1. Partisipasi dalam pengambilan keputusan.

2. Partisipasi dalam pelaksanaan kegiatan.

3. Partisipasi dalam pemantauan dan evaluasi pembangunan. 
4. Partisipasi dalam pemanfaatan hasil-hasil pembangunan.

Faktor-Faktor Yang Mempengaruhi Partisipasi Masyarakat dalam Musrenbang antara lain adalah :

1. Faktor lingkungan fisik, mencakup; kesuburan tanah, jenis tanah, iklim, topografi dan orbitasi daerah.

2. Faktor sosial ekonomi, mencakup; jenis pekerjaan, tingkat pendapatan, tingkat pendidikan, status pemilikan rumah / lahan, jumlah tanggungan keluarga, jumlah tenaga kerja keluarga dan tingkat kesehatan.

3. Faktor sosial budaya, mencakup; norma, nilai kepercayaan, pengetahuan, sikap, status pernikahan, usia, jenis kelamin, dan simbol-simbol.

4. Faktor policy pemerintah, mencakup; sifat-sifat koordinasi kepemimpinan lembaga sosial, pendekatan untuk memonitor masyarakat dan tingkat kebebasan untuk menyatukan pendapat dan keinginan.

Bukan sesuatu hal yang mudah untuk menerapkan kata partisipasi terutama pada suatu lingkungan masyarakat tertentu dikarenakan faktor-faktor tersebut.

\section{METODE PENELITIAN}

Studi ini dilakukan dengan menggunakan tipe penelitian deskriptif explanatory yang merupakan kombinasi antara penelitian deskriptif dan penelitian explanatory. Keith Punch (2006) menuturkan penelitian deskriptif ditujukan untuk menjawab pertanyaan "apa", sementara penelitian eksplanasi akan menjawab pertanyaan "mengapa" dan "bagaimana". Kedua tipe penelitian ini digunakan untuk menemukan jawaban yang menyeluruh atas pertanyaan penelitian dalam mengidentifikasi dan mengeksplorasi transect sebagai metode pada perencanaan pembangunan partisipatif.

Pendekatan yang digunakan dalam penelitian ini adalah kualitatif. Menurut Keith Punch (2006), Model karakteristik penelitian kualitatif akan sangat memudahkan peneliti dalam menemukan dan memahami pertanyaan penelitian. Seperti yang disebutkan oleh Creswell (2009), peneliti dapat menggunakan multiple methods that are interactive and humanistic. 
Creswell (2013 :167) mengemukakan alasan menggunakan metode kualitatif karena pendekatan ini memiliki kelebihan dalam mengungkap fenomena dari kebiasaan lazim pemerintahan desa dalam menyusun perencanaan pembangunan. Selanjutnya, karena pendekatan kualitatif mempunyai fleksibilitas yang tinggi bagi peneliti ketika menentukan langkah-langkah penelitian. Penelitian kualitatif juga dapat memberi kesempatan ekspresi dan penjelasan yang lebih besar dalam bentuk penafsiran berdasarkan kepastian intuitif secara logis. Pada penelitian kualitatif peneliti juga dapat sekaligus berperan sebagai participant observer (partisipan pengamat) dengan kegiatan seperti mencatat, merekam dan mengamati (Jamaluddin Ahmad, 2015 :52).

\section{SUMBER DATA}

Sumber data dalam penelitian adalah subyek dari mana data dapat diperoleh. Dijelaskan juga bahwa sumber data diklasifikasikan menjadi tiga yaitu: Person, Place, dan Paper. Dalam penelitian ini salah satu sumber data yang diperlukan adalah informan. Menurut Moleong (2006:132), informan adalah orang yang dimanfaatkan untuk memberikan informasi dan data tentang situasi dan kondisi dari latar penelitian. Untuk mengambil sampel atau informan dalam penelitian ini menggunakan teknik pengambilan purposive sampling.

Menurut Sugiyono (2009:96) purposive sampling adalah teknik penentuan sampel dengan pertimbangan tertentu. Sampel ini lebih cocok di gunakan untuk penelitian kualitatif, atau penelitian-penelitian yang tidak melakukan generalisasi. Dalam penelitian ini metode yang digunakan berdasarkan pada pertimbanganpertimbangan bahwa informan yang telah ditetapkan memiliki kompentensi, pengetahuan yang cukup, dan kredibilitas untuk menjawab setiap pertanyaanpertanyaan dalam pelaksanaan wawancara. Adapun key Informan dari penelitian ini adalah Kepala Desa, Kepala Urusan Pemerintahan , Kepala Urusan Kesejahteraan dan Pembangunan ,Ketua Badan Permusyarawatan Desa, Tokoh Masyarakat. 


\section{TEKNIK PENGUMPULAN DATA}

Untuk memperoleh data yang akurat, relevan, dan dapat dipertanggungjawabkan maka peneliti menggunakan beberapa teknik dalam pengumpulan data karena masing-masing mempunyai kelebihan dan kekurangan. Adapun beberapa teknik pengumpulan data dalam penelitian ini, yaitu: Observasi, proses pengambilan data dalam penelitian di mana peneliti atau pengamat dengan mengamati kondisi yang berkaitan dengan fokus penelitian. Wawancara, adalah proses percakapan dengan maksud tertentu. Wawancara ini bertujuan untuk mendapatkan pandangan atas penggunaan metode lazim yang digunakan dalam perencanaan pembangunan, penggunaan metode transect sebagai metode partisipatif, serta upaya pelibatan semua elemen masyarakat dan pihak terkait dalam berbagai perencanaan pembangunan yang partisipatif. Studi kepustakaan (library research), yaitu dengan membaca buku, dokumendokumen, undang-undang, dan media informasi lainnya yang berkaitan dengan transect, dan perencanaan pembangunan partisipatif. Jamaluddin Ahmad (2015).

\section{TEKNIK ANALISIS DATA}

Penelitian deskriptif dimaksudkan untuk menggambarkan fenomenafenomena yang terjadi di lapangan terutama berkaitan dengan masalah yang diteliti. Data yang diperoleh di lapangan selanjutnya dianalisis dengan pemaparan serta interpretasi secara mendalam. Teknik yang digunakan dalam penelitian ini adalah Analisis Data Model Interaktif (Interactive Model Of Analysis) yang dikembangkan oleh Miles dan Huberman (Sugiyono : 2015). Teknik tersebut mengemukakan aktivitas dalam analisis data kualitatif dilakukan secara interaktif dan berlangsung secara terus menerus sampai tuntas, sehingga datanya jenuh. 


\section{DAFTAR PUSTAKA}

Adam Latif 1, Irwan2, A. M. (2019). Analisis Kepemimpinan Terhadap Optimalisasi Masyarakat Pada Perencanaan Pembangunan Di Enrekang. 120.

Mustanir, A., \& Yasin, A. (2018). Transect Pada Perencanaan Pembangunan Partisipatif. 8(2), 21-31.

Ahmad Mustanir1), Kamaruddin Sellang2), Akhwan Ali3), Madaling4), M. (2018). PERANAN APARATUR PEMERINTAH DESA DAN PARTISIPASI MASYARAKAT DALAM MUSYAWARAH PERENCANAAN PEMBANGUNAN DI DESA TONRONGNGE KECAMATAN BARANTI KABUPATEN SIDENRENG RAPPANG. Ilmia Clean Goverment, 2(1), 67-84.

Ahmad Mustanir1), M., \& Andi Uceng3), M.Nurzin R. Kasau4), B. D. A. (2019). KARAKTERISTIK KEPEMIMPINAN LURAH TERHADAP PARTISIPASI MASYARAKAT DALAM MUSYAWARAH PERENCANAAN PEMBANGUNAN DI KELURAHAN DUAMPANUA KECAMATAN BARANTI KABUPATEN SIDENRENG RAPPANG Oleh. 2(2), 145-172.

Ahmad Mustanir, D. (2016). Implementasi kebijakan dana desa dan partisipasi masyarakat dalam pembangunan di desa teteaji kecamatan tellu limpoe kabupaten sidenreng rappang. 04(2).

Ahmad Mustanir, P. A. (2017). Partisipasi masyarakat dalam musyawarah rencana pembangunan di kelurahan kanyuara kecamatan watang sidenreng kabupaten sidenreng rappang. Jurnal Politik Profetik, 5(2).

Aldina, D. (2017). DESA SEI ALIM ULU KECAMATAN AIR BATU SKRIPSI Diajukan Oleh : Dini Aldina S PROGRAM STUDI SOSIOLOGI.

Mustanir, A., Fitriani, S., Adri, K., Nurnawati, A. A., \& Goso, G. (2020). 
Sinergitas Peran Pemerintah Desa dan Partisipasi Masyarakat Terhadap Perencanaan Pembangunan di Kabupaten Sidenreng Rappang (The Synergy of Village Government's Role and Community Participation in the Process of Development Planning in Sidenreng Rappang D. Journal of Government Science (GovSci), 2020, 1(2): 84-108, 2020(2), 84-108.

Mustanir, Ahmad; Abadi, Partisan. 2016. "PARTISIPASI MASYARAKAT DALAM MUSYAWARAH RENCANA PEMBANGUNAN DI KELURAHAN KANYUARA KECAMATAN WATANG SIDENRENG KABUPATEN SIDENRENG RAPPANG."

Mustanir, Ahmad, Herman Dema, Haeruddin Syarifuddin, Kiki Meity, and Sri Wulandari. 2018. "Pengaruh Motivasi Dan Partisipasi Masyarakat Terhadap Pembangunan Di Kelurahan Lalebata Kecamatan Panca Rijang Kabupaten Sidenreng Rappang.

Mustanir, Ahmad, Kamaruddin Sellang, Akhwan Ali, Madaling Madaling, and Mutmainna Mutmainna. 2018. "PERANAN APARATUR PEMERINTAH DESA DAN PARTISIPASI MASYARAKAT DALAM MUSYAWARAH PERENCANAAN PEMBANGUNAN DI DESA TONRONGNGE KECAMATAN BARANTI KABUPATEN SIDENRENG RAPPANG.” Jurnal Ilmiah Clean Government (JCG) 2 (1): 67-84. http://lonsuit.unismuhluwuk.ac.id/index.php/clean/article/view/213.

Mustanir, A., \& Yasin, A. (2018). Transect Pada Perencanaan Pembangunan Partisipatif. 8(2), 21-31.

Mardikanto, Totok dan Poerwoko Soebiato. 2015. Pemberdayaan Masyarakat Dalam Perspektif Kebijakan Publik. Bandung : Alfabeta (JCG) 2 (1): 27-39.

http://lonsuit.unismuhluwuk.ac.id/index.php/clean/article/view/212.

Pratama, M. R., Azikin, R., Ilmu, J., Negara, A., Makassar, U., Ilmu, J., Negara, A., Makassar, U., Ilmu, J., Negara, A., \& Makassar, U. (2018). 
PELAKSANAAN MUSYAWARAH PERENCANAAN PEMBANGUNAN DESA

DI DESA UJUNG MATTAJANG KECAMATAN MAPPEDECENG

KABUPATEN LUWU UTARA Muh. 4(April), 34-51.

Latif, Adam, Irwan Irwan, Muhammad Rusdi, Ahmad Mustanir, and Muh

Sutrisno. 2019. "Partisipasi Masyarakat Dalam Pembangunan Infrastruktur

Di Desa Timoreng Panua Kecamatan Panca Rijang Kabupaten Sidenreng

Rappang.” MODERAT: Jurnal Ilmiah Ilmu Pemerintahan Universitas Galuh

Ciamis 5 (1): 1-15.

Sumampow3, R. T. M. K. I. (2018). PARTISIPASI MASYARAKAT DALAM

PELAKSANAAN MUSYAWARAH PEMBANGUNAN (MUSREMBANG) DI DESA SONSILO KECAMATAN LIKUPANG BARAT. 2.

Sjafrizal, 2009. Teknik Praktis Penyusunan Rencana Pembangunan Daerah. Baduose Media.

Slamet, Y. 2002. Konsep-Konsep Dasar Partisipasi Sosial. Yogyakarta: PAU-SS UGM 